\title{
SUSTAINABLE WASTE MANAGEMENT OF TRADITIONAL CRAFT INDUSTRY IN LOPATI TOURISM VILLAGE, YOGYAKARTA
}

\author{
VITASURYA, Vincentia Reni ${ }^{*}$, PUDIANTI, Anna ${ }^{2}$ \\ ${ }^{1,2}$ Architecture Department, Universitas Atma Jaya-Yogyakarta, \\ Jalan Babarsari no 44, Yogyakarta \\ *Corresponding author: reni792003@yahoo.com
}

\begin{abstract}
Ecotourism has been growing in Yogyakarta that can be seen through the development of rural tourism. The development of rural tourism has positive impact to improve local community's welfare nevertheless, it has also negative impact onto environmental carrying capacity. Lopati tourism village is located in Bantul, Yogyakarta, relying on traditional craft industry as tourism attraction. Traditional crafts are livelihood of local residents, so that environmental management efforts become part of their daily lives. This research aims to review the roles of community to reduce environmental impacts through analyzing the waste management of traditional craft industry. It used case study method to examine the uniqueness of Lopati village. Data collecting used participatory action research techniques in order to gather information from residents. Community participation acted to anticipate negative impact on development of rural tourism. Waste management in Lopati committed by local residents not to cause adverse environmental impacts. The result show that waste management based on community participation supports the development of rural tourism.
\end{abstract}

Keywords: Ecotourism; rural tourism; waste management; environmental impact; community participation.

\section{INTRODUCTION}

Ecotourism is a relatively new tourism trend in Indonesia. Internationally, since October 1999, by WTO, it encourages countries in the world to develop sustainable tourism. Yogyakarta as a tourism city also affected by this "new trend". Culture-based tourism offers activities for creativity, taste, and imagination of mankind as a culture subject, both tangible and intangible. Culture is the embodiment of folk traditions and way of life and are illustrated in food, rituals, dances, festivals, sculptures, building design, religion, dressing and other practices. (UNESCO, 2001). It is based on mosaic of places, foods, tradition, art, ritual and experiences of someone (Wadawi et.al., 2008; Wadawi et.al., 2009).

Activity-based tourism or ecotourism and culture began to appear in Yogyakarta, especially around Bantul. Bantul district has 32 villages that have been grown and recorded. (DISPARBUDBantul, 2013). The implementation of ecotourism includes supporting sectors of tourism activities in general, i.e beach and sun tourism, rural and agro tourism, cultural tourism, or business travel. This is affirmed by Nugroho (2011) that ecotourism rests on rural tourism, nature tourism and cultural tourism should be understood as efforts to maintain a balance of environmental carrying capacity.
Traditional handicraft industries produce various waste as a result of activities that must be considered. Waste is no more treated as valueless garbage; waste is rather considered as a resource in the present time. Resource recovery is one of primary objective in sustainable waste management system (Zaman, 2012). Sustainable waste management protects human health, property, environment, and conserves valuable natural resources. An environmentally sustainable waste management system will help protect future generations from environmental degradation, associated with financial burdens (Edmonton, 2010). In tourism village, attractions such as traditional handicraft industry became part of rural tourism development that must be manage. Waste treatment is done so it does not put negative impact on the environment. It is essential to maintain a continuity of tourist activity, especially in tourism villages. This paper aims to study waste management efforts of traditional craft industry in Lopati tourism village.

\section{METHOD}

This research used a case study method based on data from field observations. Data collection used participatory methods that involve community action research (Mikkelsen, 2001). Flow chart of discussion in this research is described in Figure 1. 


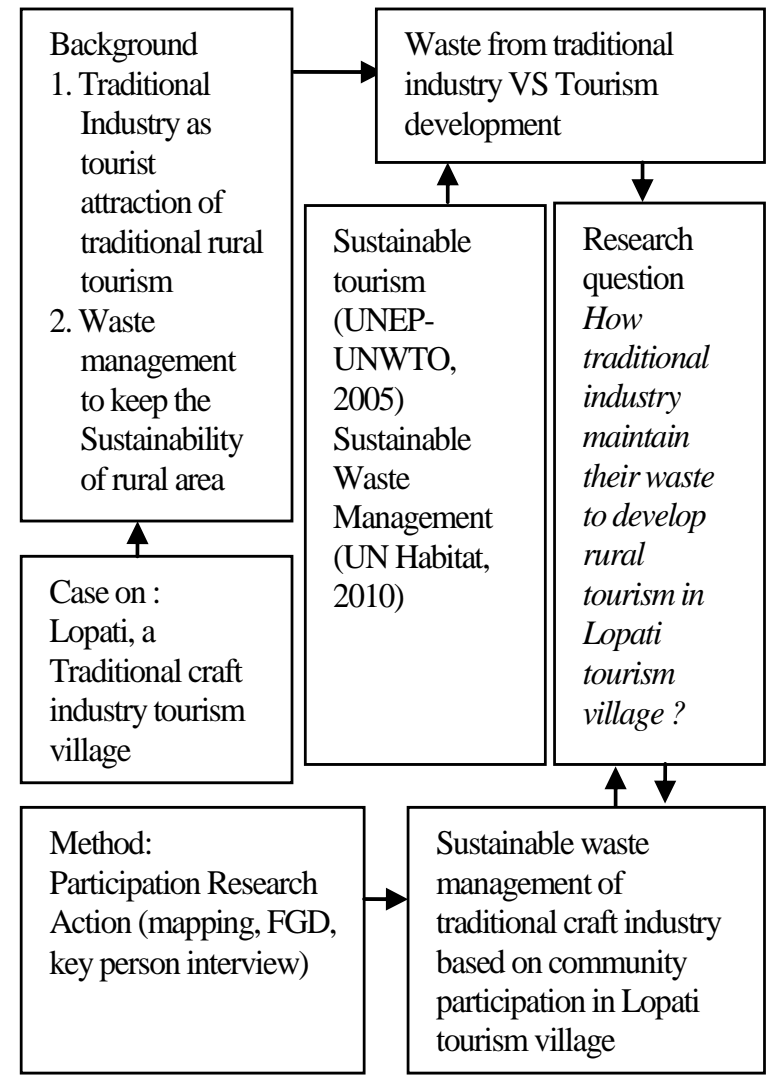

Fig. 1. Schematic flowchart (Source: author, 2016)

This study intends to study waste management efforts of traditional handicraft industry based on daily lives of rural communities in Lopati. Waste management involves community participation as player and manager in tourism villages.

\section{RESULTS and DISCUSSION}

Location of this research is in D.I.Yogyakarta province, focus in Lopati tourism village, Bantul districts. This village is well known as industrial village, which use the local tradition to run the industry. The uniqueness of this village is traditional industry that uses local material such as bamboo, cassava, soya bean and greenbean. The local residents use local plant as ingredient of daily traditional food i.e bakpia (traditional cookies made from greenbean), mie lethek (traditional nodle made from cassava) and tempeh (traditional food made from soyabean). They also use bamboo for traditional handicraft i.e kronjot (traditional bamboo basket) and batik bamboo handicraft. This local product not only became homebased industry but also became their main income. Inline with rural tourism as a new trend to develop rural area, Lopati decided to became tourism village. In 2007, Lopati officially became a tourism village. Main attraction for the tourist is traditional industry.
Traditional craft industries are quite attractive because it uses various local materials. These attractions can be seen on Figure 2.

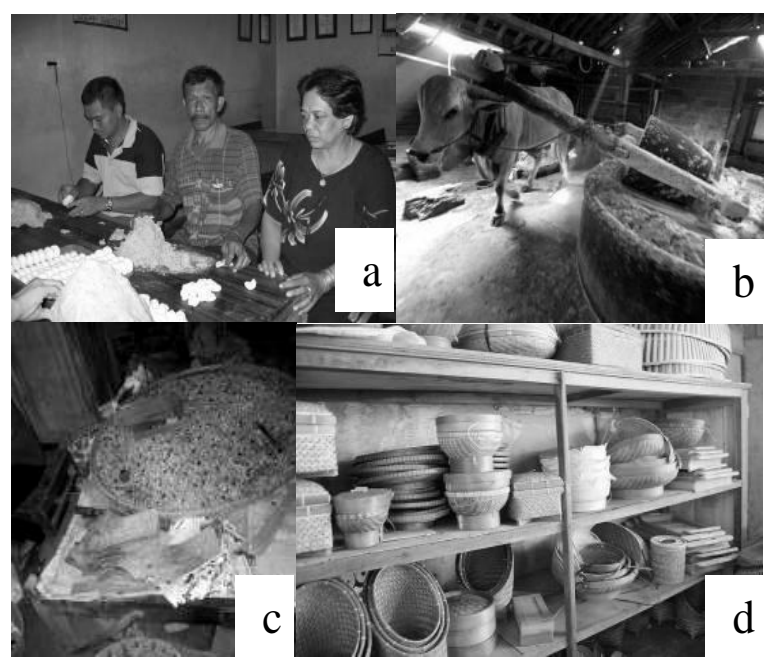

Fig. 2. Traditional industry in Lopati (a), bakpia industry, (b) mie lethek industry, (c) tempeh industry, (d) bamboo handycraft industry (Source: research doc. 2015).

Lopati tourism village located in Trimurti district, Srandakan, Bantul which is about $25 \mathrm{~km}$ to the southwest of Yogyakarta near Pandansimo beach. Location of the village can be seen through the map on Figure 3.

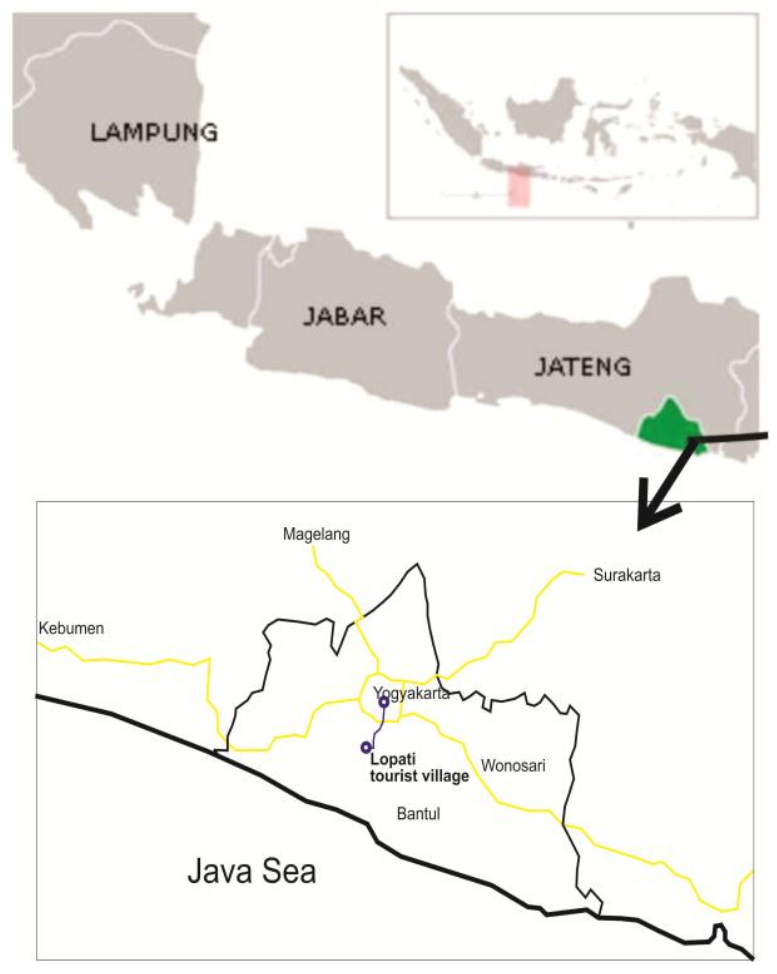

Fig. 3. Location of Lopati Village (Source: research doc. 2015). 
There are 32 traditional craft industries which are divided into 17 types of craft industry in Lopati village. The craft industry is home industry that generates few products. These industries produce waste associated to types of what are produced. Overview number of industries and waste production capacity can be seen on the Table 1 .

Tabel 1. Traditional industry capacity and amount of waste generated

\begin{tabular}{|c|c|c|c|c|}
\hline No & $\begin{array}{c}\text { Traditional } \\
\text { industry }\end{array}$ & $\begin{array}{c}\text { Number of } \\
\text { industry }\end{array}$ & $\begin{array}{c}\text { Total } \\
\text { production } \\
\text { capacity } \\
\text { (daily) }\end{array}$ & $\begin{array}{c}\text { Amount of } \\
\text { waste } \\
\text { generated } \\
\text { (daily) }\end{array}$ \\
\hline 1 & $\begin{array}{l}\text { Geplak } \\
\text { (traditional } \\
\text { coconut } \\
\text { cookies) }\end{array}$ & 2 industries & $40 \mathrm{~kg}$ & $2 \mathrm{~kg}$ \\
\hline 2 & Tempeh & 2 industries & $30 \mathrm{~kg}$ & $2 \mathrm{~kg}$ \\
\hline 3 & $\begin{array}{l}\text { Bakpia } \\
\text { (traditional } \\
\text { mung bean } \\
\text { cookies) }\end{array}$ & 3 industries & $90 \mathrm{~kg}$ & $7 \mathrm{~kg}$ \\
\hline 4 & $\begin{array}{l}\text { Peyek } \\
\text { (traditional } \\
\text { peanut } \\
\text { crackers) }\end{array}$ & 2 industries & $20 \mathrm{~kg}$ & $2 \mathrm{~kg}$ \\
\hline 5 & $\begin{array}{l}\text { Traditional } \\
\text { bread }\end{array}$ & 2 industries & $40 \mathrm{~kg}$ & $2 \mathrm{~kg}$ \\
\hline 6 & $\begin{array}{l}\text { Mie Lethek } \\
\text { (traditional } \\
\text { noodle) }\end{array}$ & 1 industry & $40 \mathrm{~kg}$ & $5 \mathrm{~kg}$ \\
\hline 7 & $\begin{array}{l}\text { Јати (herbal } \\
\text { drink) }\end{array}$ & 3 industries & $60 \mathrm{lt}$ & $2 \mathrm{~kg}$ \\
\hline 8 & Milk industry & 2 industries & $20 \mathrm{~kg}$ & $4 \mathrm{~kg}$ \\
\hline 9 & Salted egg & 2 industries & $10 \mathrm{~kg}$ & $2 \mathrm{~kg}$ \\
\hline 10 & Tofu & 2 industries & $30 \mathrm{~kg}$ & $2 \mathrm{~kg}$ \\
\hline 11 & $\begin{array}{l}\text { Batik bamboo } \\
\text { handicraft }\end{array}$ & 2 industries & $\begin{array}{c}\text { Each } 20 \text { pcs (art } \\
\& \text { craft } \\
\text { product) } \\
\text { Total } 20 \mathrm{~kg}\end{array}$ & $5 \mathrm{~kg}$ \\
\hline 12 & Furniture & 3 industries & $\begin{array}{c}\text { Each } 1 \\
\text { furniture a } \\
\text { week }(15 \mathrm{~kg} \\
\text { average }) \\
\text { Total } 10 \mathrm{~kg}\end{array}$ & $2 \mathrm{~kg}$ \\
\hline 13 & $\begin{array}{l}\text { Coconut shell } \\
\text { charcoal }\end{array}$ & 1 pengrajin & $40 \mathrm{~kg}$ & $5 \mathrm{~kg}$ \\
\hline 14 & Koro tempeh & 1 industries & $15 \mathrm{~kg}$ & $2 \mathrm{~kg}$ \\
\hline 15 & $\begin{array}{l}\text { Bamboo } \\
\text { handicraft }\end{array}$ & 2 industries & $20 \mathrm{~kg}$ & $5 \mathrm{~kg}$ \\
\hline 16 & Leather craft & 1 industries & $20 \mathrm{~kg}$ & $3 \mathrm{~kg}$ \\
\hline 17 & Farming & 1 industries & $20 \mathrm{~kg}$ & $5 \mathrm{~kg}$ \\
\hline
\end{tabular}

Source: Research data, 2015

Based on these data, we can conclude that daily home industrial generated little waste from each industry. This is because their production capacity is not much and their characteristic as home based industry.

Traditional handicraft industries produce waste that could have environmental impacts. Waste, both solid waste or liquid waste, can be generally grouped into Municipal Solid Waste (MSW). Municipal solid wastes (MSW) is often described as the waste that is produced from residential and industrial (non-process wastes), commercial and institutional sources with the exception of hazardous and universal wastes, construction and demolished wastes, and liquid wastes (water, wastewater, industrial processes). (Tchobanoglous \& Kreith, 2002).

Type of waste from traditional craft industry is largely organic waste that can be recycled. This is because home industrial raw materials are organic materials derived from local crops and livestocks. Overview types of industrial wastes in Lopati traditional craft can be seen on Figure 4.

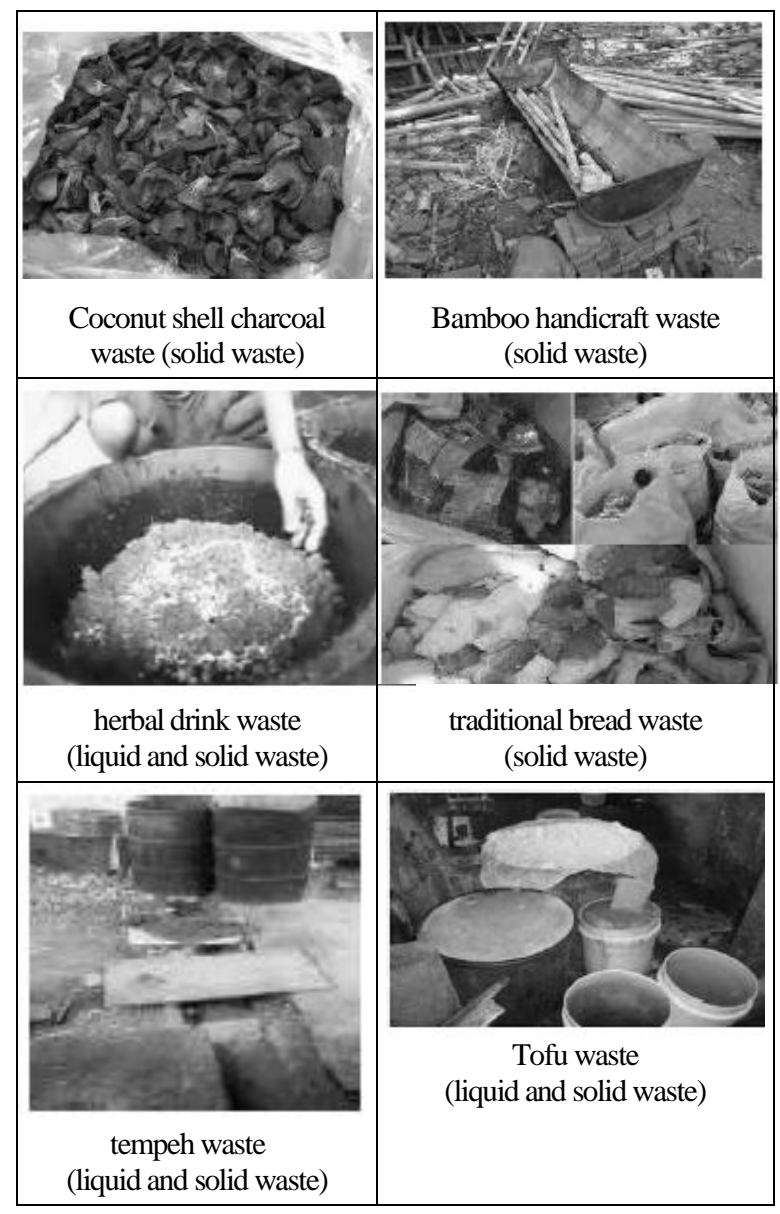

Fig. 4. Various type of waste from traditional craft industry in Lopati village (source: research doc. 2015).

Traditional craft industry waste management in Lopati tourism village simply have applied concept of sustainable waste management. Sustainable Waste Management principles include equity (for all citizens that are entitled to an appropriate waste management system due to environmental health reasons, promote the health issues for resident and tourist, and minimize the waste production for resident in island), effectiveness (related to safe removal of waste mana- 
gement, protection of environmental quality and sustainability, and maximing 3R), efficiency and sustainability of solid waste management related to increasing the benefits and decreasing the costs. (Shamshiry, Nadi, BinMokhtar \& Komoo, 2011).

There are 17 types of handicraft industries in Lopati tourism village, each of them can generate waste. Traditional craft industry waste management in Lopati village is simple, first step taken by the residents, by collecting and filtering wastewater, composting and recycling or reusing solid waste. Traditional craft industry waste management in Lopati village can be viewed through the following Table 2.

Final results of wastewater discharged through sewer can be measured by its pollution levels. Sampling technique used its wastewater traditional food processing industries i.e "geplak" traditional coconut cookies ( 2 craftsmen), "bakpia" traditional mung bean cookies (3 craftsmen), "tempeh" (2 craftsmen) and tofu ( 2 craftsmen). Traditional food industries become dominant in Lopati, percentage of traditional food craftsmen reached $65 \%$ of the total handicraft industry contained in Lopati. (Purwaningsih et.al. 2015). Measurements using samples tested by assay methods of waste in "Balai besar Teknik kesehatan lingkungan dan Pengendalian Penyakit Yogyakarta" (Office of environment health and disease control of Yogyakarta). Content of Biological On Demand (BOD), Chemical On Demand (COD) and Total Suspender Soil (TSS) are indicators of water quality. (KESMAS, 2015). Wastewater produced from some of traditional craft industries which have been tested, on average does not produce environmental problems when discharged through sewer. Wastewater test results is on Table 3.

Tabel 2. Waste treatment identification of Traditional Craft Industry in Lopati village

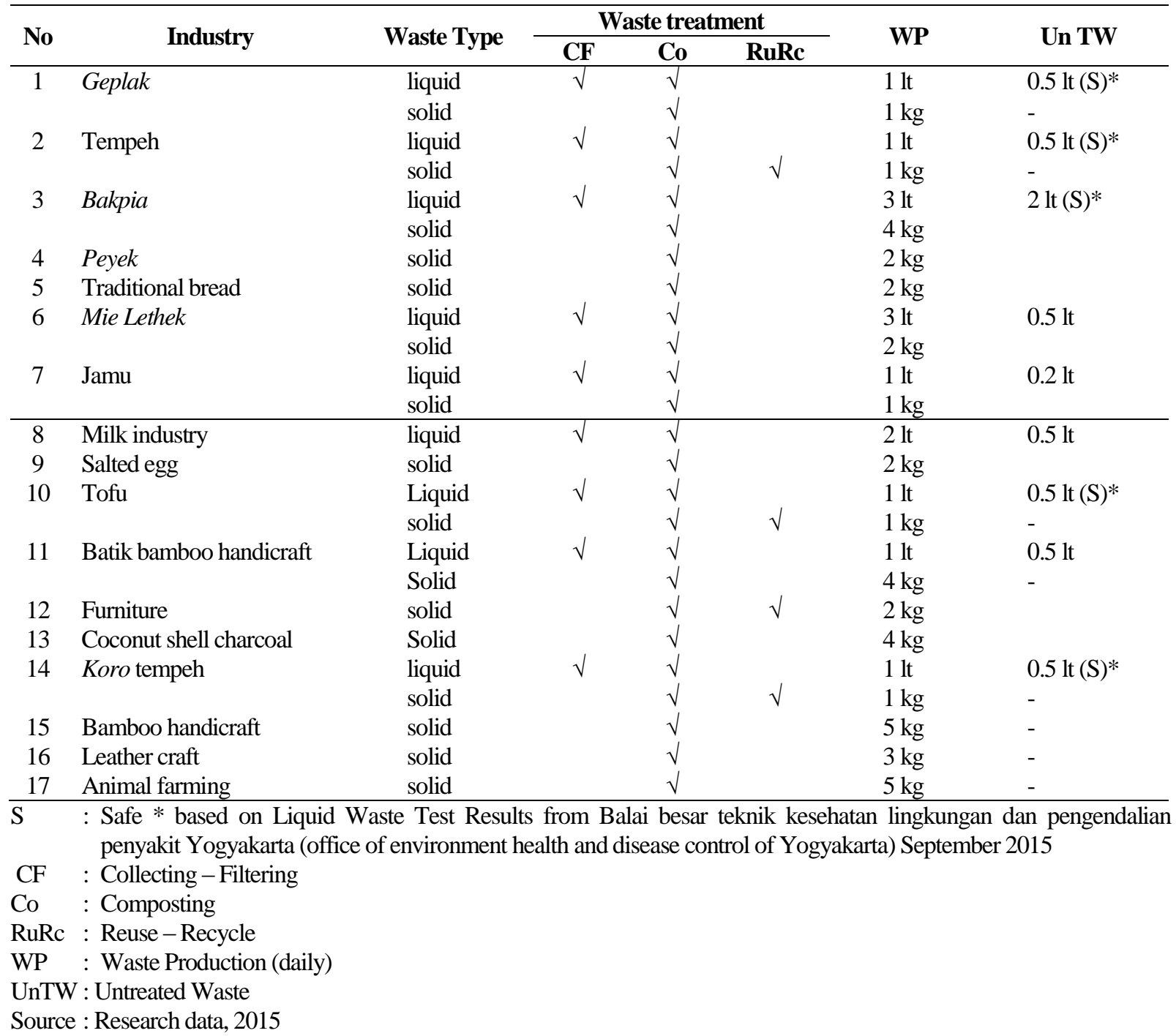


Table 3. Test results of wastewater from handicraft industry in Lopati village

\begin{tabular}{|c|c|c|c|c|c|}
\hline No & Kind of waste & BOD & COD & TSS & Raw effluent standard \\
\hline 1 & Geplak & $6 \mathrm{mg} / \mathrm{L}$ & $11,25 \mathrm{mg} / \mathrm{L}$ & $82 \mathrm{mg} / \mathrm{L}$ & $\begin{array}{l}* \mathrm{BOD}: 50 \mathrm{mg} / \mathrm{L} \\
\mathrm{COD}: 125 \mathrm{mg} / \mathrm{L} \\
\mathrm{TSS}: 200 \mathrm{mg} / \mathrm{L}\end{array}$ \\
\hline 2 & Tempeh & $8 \mathrm{mg} / \mathrm{L}$ & $31 \mathrm{mg} / \mathrm{L}$ & $1,33 \mathrm{mg} / \mathrm{L}$ & $\begin{array}{l}* * \mathrm{BOD}: 75 \mathrm{mg} / \mathrm{L} \\
\mathrm{COD}: 200 \mathrm{mg} / \mathrm{L} \\
\mathrm{TSS}: 75 \mathrm{mg} / \mathrm{L}\end{array}$ \\
\hline 3 & Bakpia & $6 \mathrm{mg} / \mathrm{L}$ & $11,25 \mathrm{mg} / \mathrm{L}$ & $82 \mathrm{mg} / \mathrm{L}$ & $\begin{array}{l}* \mathrm{BOD}: 50 \mathrm{mg} / \mathrm{L} \\
\mathrm{COD}: 125 \mathrm{mg} / \mathrm{L} \\
\mathrm{TSS}: 200 \mathrm{mg} / \mathrm{L}\end{array}$ \\
\hline 4 & Tofu & $8 \mathrm{mg} / \mathrm{L}$ & $31 \mathrm{mg} / \mathrm{L}$ & $1,33 \mathrm{mg} / \mathrm{L}$ & $\begin{array}{l}* * \text { BOD : } 75 \mathrm{mg} / \mathrm{L} \\
\text { COD : } 200 \mathrm{mg} / \mathrm{L} \\
\mathrm{TSS}: 75 \mathrm{mg} / \mathrm{L}\end{array}$ \\
\hline 5 & Koro Tempeh & $8 \mathrm{mg} / \mathrm{L}$ & $31 \mathrm{mg} / \mathrm{L}$ & $1,33 \mathrm{mg} / \mathrm{L}$ & $\begin{array}{l}* * \mathrm{BOD}: 75 \mathrm{mg} / \mathrm{L} \\
\mathrm{COD}: 200 \mathrm{mg} / \mathrm{L} \\
\mathrm{TSS}: 75 \mathrm{mg} / \mathrm{L}\end{array}$ \\
\hline
\end{tabular}

*Other Raw effluent standard based on DIY Governor's decree no 7 in 2010

**Tempeh and Tofu Raw effluent standard based based on DIY Governor's decree no 7 in 2010

Source: research data (2015)

BOD (Biochemical Oxygen Demand) is a measurement parameter of oxygen needed by bacteria to decompose almost all organic substances dissolved and suspended in waste water, expressed by BOD 5 days at $20^{\circ} \mathrm{C}$ in $\mathrm{mg} / 1$ or ppm. (KESMAS, 2015). This measurement is important because if waters polluted by organic matter, bacteria can spend oxygen dissolved in the water during the process of biodegradable underway, so can result in the death of aquatic fauna and water conditions can become anaerobic, which is marked by emergence of stench. COD (Chemical Oxygen Demand) is amount of oxygen required to oxidize organic substances contained in wastewater by utilizing an oxidant potassium dichromate as a source of oxygen. COD number is a measure of water pollution by organic substances that naturally can be oxidized through biological processes and can lead to reduced oxygen dissolved in water. (KESMAS, 2015). While TSS (Total Suspended Solid) is a substance which is suspended usually consists of organic and inorganic substances floating in water, physically this substance is causing turbidity in water. Wastewater which has high content of suspended substances must not be discharged directly into waters, because not only can cause silting up but also can block incoming sunlight into the bottom of the water, so that process of photosynthesis microorganisms cannot take place. (KESMAS, 2015). All three indicator may be a preliminary description of waste from traditional craft industry in Lopati village. Based on this study, it appears that final effluent from waste, especially wastewater in Lopati, does not produce the environmental pollution.
For solid effluent, the process is done by making compost, which can be used as fertilizer. Some types of solid waste results, such as tempeh and tofu dregs are used for additional fodder, i.e: goats and ducks. Other treatment of solid waste is to recycle. For example, wood waste from furniture industry is used as additional materials for bamboo craft.

Overview of sustainable waste management in Lopati can be seen in a scheme based on Sustainable waste management on the following waste hierarchy (Unnisa \& Rav, 2012) ie: 1. Reduce or prevent waste arising: waste minimization initiatives to help businesses and households reduce the amount of waste that they create, 2. Reuse waste: reuse waste and thus avoid energy-consuming reprocessing, 3. Recycle: reprocess waste for further use, 4. Energy recovery: generating energy from waste using a variety of technologies, 5. Disposal: put waste in landfill sites. Implication at Lopati village can be describe on table 4.

Table 4. Implication of Sustainable Waste Management hierarchy in Lopati village

\begin{tabular}{cll}
\hline No & \multicolumn{1}{c}{ Action } & \multicolumn{1}{c}{ Implication in Lopati village } \\
\hline 1 & $\begin{array}{l}\text { Reduce or prevent } \\
\text { waste arising }\end{array}$ & Used local material for ingredient \\
2 & $\begin{array}{l}\text { Reuse waste } \\
\text { Solid waste for animal feed (from }\end{array}$ & $\begin{array}{l}\text { Solid } \\
\text { tempeh industry) and fertilizer } \\
\text { (from bakpia industry) }\end{array}$ \\
4 Recycle & $\begin{array}{l}\text { Solid waste from bamboo furniture } \\
\text { became batik bamboo handicraft }\end{array}$ \\
5 Energy recovery & $\begin{array}{l}\text { Solid waste from coconut became } \\
\text { coconut shell charcoal } \\
\text { Communal landfill sites to collect } \\
\text { waste from all industry }\end{array}$ \\
\hline
\end{tabular}

Source: Research analysis, 2016 
Waste management in Lopati village is a community-based management. Test results showed that the waste is safely discharged into the environment because local community are using natural and organic raw materials for production. Some examples can be seen in tempe processing that does not use artificial ingredients so that the dregs produced is safe for cattle. Industrial solid waste furniture process also can be reused for bamboo craft industry. Scale of industries which are households with small production output also affect waste generated. Most industries are done by family members of the villagers in Lopati village. People are realizing if waste generated pollute environment then the impact will be affected on their own. Within context of rural development as a tourism village in Lopati, this condition should retained so that a sustainable environment can be maintained.

\section{CONCLUSION}

Community-based waste management of industrial handicraft in Lopati village, does not pollute the natural environment. Handicraft industry in Lopati village is a homebased industry in small scale production. It can retained because the development of tourism activities in Lopati village, so traditional industry is no longer pursuing a large quantity, but community still get additional results from tourism attractions craft.

Waste management of traditional handicrafts in Lopati produces waste that does not pollute the environment because:

1. Waste types is organic waste which can be recovered, this is because raw materials for tradistional industry use natural ingredients.

2. Reusing industrial waste into fertilizer, mixed from animal feed and raw materials of crafts industry. This re-utilization, reducing final waste product that will be discharged to the environment

Thus, on a simple scale, industrial waste management in Lopati traditional craft village can support the development of tourism village based education tourism craft. Management of this waste can be an example of sustainable waste treatment by considering long-term impact. This condition can be maintained if local community work together to manage the commitment scheme of sustainable rural development.

\section{ACKNOWLEDGMENT}

Appreciation is intended to research team of "Pusat Studi Kewirausahaan (PUSWIRA)"/Entre- preneurship Research Center Universitas Atma Jaya Yogyakarta which has give opportunity to do research in Higher Education scheme COMPETITIVE GRANTS in 2015. Author is also to thank for all support of the Lopati villager, who was willing to be object of this study.

\section{REFERENCES}

DISPARBUD-Bantul (2013). Data Desa Wisata Kabupaten Bantul. Bantul: Pemerintah Kabupaten Bantul.

Edmonton, C.O. (2010). Sustainable Waste Management. Retrieved October 17, 2016, from https://www.edmonton.ca/:https://www.edmont on.ca/city_government/documents/PDF/Discuss ion_Paper_10_Sustainable_Waste_Management .pdf

KESMAS (2015). Pengertian BOD, COD, TSS, pada Air Limbah. Retrieved October 20, 2016, from http://www.indonesian-publichealth.com/ pengertian-bod-cod-tss-pada-air-limbah/

Mikkelsen, B. (2001). Metode Penelitian Partisipatoris dan Upaya - upaya Pemberdayaan (terjemahan) (2nd ed.). Jakarta: Yayasan Obor Indonesia.

Nugroho, I. (2011). Ekowisata dan Pembangunan Berkelanjutan. Yogyakarta: Pustaka Pelajar.

Purwaningsih, A., Herawati, A. \& Vitasurya, V. R. (2015). Model Pemberdayaan Desa Wisata Berbasis Pelestarian Lingkungan Dalam Upaya Peningkatan Kesejahteraan Masyarakat Di Provinsi Daerah Istimewa Yogyakarta. Yogyakarta: Universitas Atma Jaya Yogyakarta.

Shamshiry, E., Nadi, B., BinMokhtar, M. \& Komoo, I. (2011). Integrated Models for Solid Waste Management in Tourism Regions: Langkawi Island, Malaysia. Journal of Environmental and Public Health , p.1-5.

Tchobanoglous, G. \& Kreith, F. (2002). Handbook of solid waste management. New York: McGRAWHILL.

UNESCO (2001). UNESCO Universal Declaration on Cultural Diversity. Retrieved March 29, 2014, from http://www.portal.unesco.org/ev. php.htm

Unnisa, S. A. \& Rav, S. B. (2012). Sustainable Solid Waste Management. Canada: Apple Academic Press.

Wadawi, Bresler, J. \& Okech, R. (2008). Using hotel quality differentiating factors to boost Kenya's destination competitiveness. International Journal of Tourism and Travel, 1(1), p.22-32. 
Wadawi, J., Bresler, N. \& Okech, R. (2009). The Role of hotels in the consumption of cultural tourism in Kenya. Journal of Tourism Studies and Research, 8(8), p. 34-39.

WTO. (1999). Global Code of Ethic for Tourism. Santiago, Chile.
Zaman, A. (2012). Comparative Study of Municipal Solid Waste Treatment Technologies Using LIfe Cycle Assessment Method. In S. A. Unnisa, \& S. B. Rav, Sustainable Solid Waste Management (p.1-14). Canada: Apple Academic Press. 